\title{
Laptop Computers: Reflecting on Innovation in Science
}

\author{
Morag S. Gundy and Marie Josée Berger
}

\begin{abstract}
This paper presents a study on teacher's reflections. This descriptive, qualitative, study provided an opportunity for high school biology teachers to reflect on their experiences as they implemented an innovation, laptop computers, in their laboratory classrooms. Their reflections were analyzed in terms of how the innovation was accomplished, including their role, teaching approaches, and the acquisition and use of teaching materials.
\end{abstract}

Index Terms-Biology, implementation, instruction, laptops, reflection, teachers.

\section{INTRODUCTION}

Research studies have consistently indicated that teachers, especially teachers in the senior high school grades and teachers of science, have not integrated computers, even laptop computers, into their instruction to the extent the researchers anticipated [1]-[3]. Existing studies on the implementation of laptops have tended not to focus on the role of the teachers, focusing instead on student attitudes and measuring possible gains in student achievement [4], [5]. Laptop computers were first introduced into Australian schools in the late 1980s [1], but integrating laptop computers into instruction remains a more recent innovation in Canadian schools and elsewhere around the world. While early research appears to support the premise that the use of laptops may improve instruction by decreasing teacher-centred instruction and increasing student-centred learning [6], the introduction of laptops does not automatically entail a change in modes of instruction.

Some teachers in France and the United States, for example, were found to be using laptops as an add-on, with little change in their teacher-centred instructional practices [7], [8]. Yet, researchers have also observed that teachers with strong subject matter knowledge tend to employ, or at least consider, more effective or innovative teaching strategies [9], [10], and confirmed that biology teachers bring creativity and commitment to the integration of innovations in their classrooms [11].

Despite a lack of studies focusing on the role of the teachers, a number of researchers have concluded that whether innovations, such as laptop computers, are integrated into instruction, and how they are integrated, depends on decisions made by individual classroom teachers [12], [13]. There is a need to describe and interpret teachers' reflections about the process they undertook, and how they

Manuscript received September 12, 2012; revised December 29, 2012.

Morag S. Gundy is with University of Ottawa, Canada (e-mail: moragsgundy@hotmail.com).

Marie Josée Berger was with the Ontario Institute for Studies in Education, University of Toronto. She is now with the Faculty of Education, University of Ottawa, Canada (e-mail:mjberger@uottawa.ca). accomplished the innovation.

\section{DESIGN OF THE STUDY}

\section{A. Qualitative Research}

Qualitative research can be used to collect data on 'how' questions where the researcher has no control over the actual event being studied [14] and to study phenomena that take a long time to happen, which evolve along the way, and where it often takes a long time to understand what is going on [15]. The study described in this paper was designed to allow biology teachers to describe their experiences: it was not designed to test hypotheses or develop theory.

Descriptive studies have greatly increased knowledge of what goes on in schools [16] since they explore actions, events, frames of reference, and processes in natural settings such as classrooms. This descriptive qualitative study stresses the importance of the context in which biology teachers teach, and seeks to hear their voices and understand their lived experiences as they integrated an innovation, laptop computers, into their high school biology programs [17].

\section{B. The Participants}

A purposeful sample [18], [19] was sought of ten teachers who were teaching biology in the final two years of high school, in laptop environments where teachers and students have access to personal laptops and the same software. Sites were sought in Ontario, Canada.

All ten teachers who volunteered to participate in the study had strong backgrounds in science and biology and were academically well-prepared to teach high school biology courses. All had undergraduate degrees in science from Ontario universities. In addition, they reported having completed additional undergraduate credits in chemistry, physics, radiation biophysics, neural anatomy, and psychology. Five had graduate degrees: four had a M.Sc. or M.A. in science, one had an M. Ed. in curriculum studies, and two of these teachers had started, or had been about to start, a Ph.D. program in science when they decided to return to teaching high school science. Some had chosen not to teach with the desktop computers available at their schools. Other teachers in the sample had begun their teaching careers in laptop schools

\section{Data Collection and Analysis}

Having chosen to conduct a qualitative descriptive study, appropriate strategies for collecting data were selected [20]. Three semi-structured one hour interviews were conducted with each teacher. Inductive analysis of the data followed the data collection [18], [19]. Data collected were analyzed in a process described as "uncovering and discovering themes that run through the raw data, and interpreting the implication 
of those themes" [21].

\section{RESUlTS AND DisCUSSION}

\section{A. Reflections on How the Innovation Was Accomplished}

Teachers in the study indicated that they decided how to integrate the laptops into instruction and that they recognized that how they, as individuals, chose to integrate the laptop computers was possibly unique among their colleagues. While the teachers reported some collaboration with colleagues on academic matters or content, only a few teachers described having shared lesson plans, or planning with teaching partners. In addition, only occasionally was it noted that the Instructional Technology (IT) department assisted with software the teachers wished to use for teaching in biology. All the teachers described a gradual or evolutionary pattern of integrating laptop computers into their instruction over two or three years.

Over a period of time. I think it was a bit of an adjustment for the students as well as the teachers, so it didn't happen quickly (Adele, I - 247).

The pedagogical decision-making pattern described above was very different from the process the teachers described for the integration of hardware and software to be used throughout the school by teachers in all subjects. In this latter instance, where the laptops were used for administrative or non-pedagogical purposes, the teachers did not make the decisions as to what would be integrated or when an innovation would be implemented, and IT departments provided appropriate and timely professional development.

By contrast, when talking of the challenges in finding appropriate pedagogical professional development and models for instruction in their biology courses, a sense of isolation was communicated.

It's important for groups of individuals that are perhaps using this (laptops) in some fashion to get together, and share best practices and to discuss things that might be possible. If we could do that, we might be able to take away from that something that would help us. (Keith, III-73).

The teachers anticipated that the innovations would be ongoing for a number of reasons, including: they might be teaching different courses; changes in provincial curriculum guidelines; changes in teaching partners; new hardware; new software programs they wanted to introduce; and, innovations they would introduce to reflect student needs. Most report that they had reached the point in the integration process where they were now substituting better labs and better data gathering experiences for the students.

\section{REFleCtions on Role AND TEACHING APPROACHES}

When asked what had affected their role in the classroom and their teaching approaches, a number of themes emerged including: the students, the schools, professional development, changes in instruction and, their characteristics as teachers.
Teachers cited positive, if anecdotal, feedback from students and alumnae/i. Students described feeling better prepared for post-secondary studies through participation in the laptop program; and, alumnae/i reported feeling better prepared to succeed at the post-secondary level.

The teachers stressed the effect of the school, sometimes identified as "the administration" or "the IT department", in supporting the integration of the laptop computers in their classrooms. For most of these teachers, evidence of this support is the provision of the peripherals needed to teach biology with laptop computers, and the provision of up-to-date technology. Having professional development at the school was seen as a great advantage, preferably at times scheduled into their timetables, and preferably to address the needs they as teachers identified.

How can this be done now? PD? I would say through teachers sharing how to integrate laptops into teaching. It has to be sharing sessions and my idea, which I'd love to see happen in the future, would be to actually host a technology conference of some sort where teachers share (Darby, II 39).

These teachers described being encouraged by the fact that the school had designated funds for them to attend conferences, workshops, and/or courses as well as noting the importance of financial support through the IT department's budget.

I'd emphasize the necessity of having a lot of financial support because IT in biology, certainly when I think of the money I spent just recently on probes, is sometimes an entire science department budget at certain schools (Xandra, III 129).

Teachers observed that innovations they had already made in instructional approaches encouraged them to continue the process of integrating laptops into their biology programs, although the reasons provided were variable. Many described learning from the students as they integrated the laptops and being stimulated by the students' increased interest in the biology course, as well as by the increase they perceived in student learning and student motivation. Other teachers said they had been encouraged to continue since they could fit the integration of laptops into their approach to teaching biology. Another noted that once a school is in a laptop program there is no going back, since all the schools most comparable to the school where he was teaching had introduced laptop programs.

Personal characteristics, perhaps unique to them as individual teachers which encouraged them to continue the process of integrating laptop computers into their instruction, included: a positive attitude to integrating innovations; the ability to deal with the time constraints of teaching a laboratory subject; and, their increasing proficiency within the laptop program which encouraged them to continue the process. Others noted they were encouraged to continue the integration of laptop computers because they became more efficient with regard to preparing lessons and classroom teaching. Still other teachers identified improvements in the instruction of their biology courses, including: more learning 
experiences for the students; increased students' output in the laptop program; the fact that students liked the coursework more; and, the students were less stressed by the requirements of the course.

Challenges the teachers in the study associated with technological innovation included issues with hardware, software, and the peripherals used with the laptops to teach biology. Surprisingly however, many of the observations about new hardware are positive in nature, including: upgrades such as laptops with tablet and stylus capability will make it easier to teach; and more network speed and capacity, and wireless capability, will make it easier to use laptops for instruction. The unintended, sometimes negative, consequences of hardware updates, which result from the acquisition of new laptops, are noted with philosophical resignation as the price of progress. Similarly it is thought that improvements in software and upgrades in peripherals, such as probeware and SMART boards which can be controlled by touch, will make teaching in the laptop program easier or more efficient in the future. Dealing with the inevitable incompatibility between existing resources and newly acquired resources, although challenging, was again viewed as the price of progress.

Generally, teachers did not express concerns about instruction, but some noted instructional challenges. The challenges included: varying the delivery of classes when teaching with laptops; varying their teaching approaches; individualizing instruction for different classes and different students; the time and energy required to double-check teaching resources each year before they could be used in the classroom; the tedious and cumbersome process for receiving, marking, and returning student work; and, the fact that the nature of different courses (such as the Ontario Biology 11 and Biology 12 courses) presented different instructional challenges for them.

\section{REFLECTIONS ON ACQUISITION AND USE OF TEACHING MATERIALS}

The teachers who participated in this study noted the importance of up-to-date technology, having the software they required to teach biology, and the importance of acquiring new software and hardware which they anticipated would make the instructional process easier. They outlined a number of professional development activities which they consider to be important, including: hearing about integrating laptops into instruction from colleagues during staff meetings the support provided when technology "experts" were invited to the school to demonstrate new equipment to the teachers [and in one school to the students as well]; and, having colleagues present during professional development opportunities. This was seen as an advantage for follow-up after the professional development experience and for mentoring within the science department. Some said they were encouraged to continue integrating laptop computers into their instruction by standards for technology use in biology courses issued by the Ontario Ministry of Education and the International Baccalaureate, by program evaluations carried out at their school, and by the feedback they received from such program evaluations. They believed that teaching with laptops in a laboratory subject made it more difficult to schedule the blocks of time they needed in order to master and integrate new hardware, software and peripherals into their instruction, than if they had been teaching another subject in the school.

The need to provide students with more effective learning opportunities is noted by teachers, as are the associated challenges of providing a laptop program to teenagers. The teachers acknowledged that early experiences needed to be tailored to a realistic level of maturity for adolescent students. One teacher, identifying the need for feedback on his teaching approaches in the laptop program, noted that he is of the opinion that no one even has the tools to provide that type of feedback to teachers like him.

\section{CONCLUSION}

The research reported in this paper is among the first to study change in practice when integrating laptops into instruction in senior biology courses. The study contributes to the practical knowledge requisite to implement this innovation in the classroom. By concentrating on the reflections of teachers who are either charged with, or self-initiate the pedagogical integration of laptop computing in their respective senior science classrooms, our study contributes to the practical knowledge requisite to implement this innovation in the classroom.

Much of the previously existing research focusing on the integration of educational innovations studied externally motivated change where the innovation was designed and planned by experts and where the teachers were simply expected to implement the innovation provided to them in their classrooms. That existing research focused largely on the top-down implementation of well-structured innovations and gave insufficient consideration to the realities and the needs of individual teachers, including the implications of integrating poorly structured innovations, particularly innovations that would engage new technologies.

In order to address these shortcomings, our study investigated the process of innovation initiated, integrated and sustained by teachers, and characterized by a bottom-up implementation where individual teachers organize and manage the integration of innovations in their subject area and within their own classrooms by relying largely upon their personal knowledge, skill levels, and interests. By building knowledge about how teachers perceive, understand, and act to integrate laptop computing in their instructional work, this paper speaks to the broader and potentially more significant issue of how innovation can be better designed so that it can more expeditiously achieve the educational ends it would accomplish.

\section{REFERENCES}

[1] A. Bain and M. E. Weston, "The future of computers and 1:1 laptop initiatives: Which side of the border are you on?" Independent School, vol. 68 , no. 2, pp. 50-56, 2009.

[2] D. A. Coffland and A. W. Strickland, "Factors related to teacher use of technology in secondary geometry instruction," Journal of Computers in Mathematics and Science Teaching, vol. 23, no. 4, pp. 347-365, 2004.

[3] J. Mara, "Computers as ubiquitous tools for teachers and learners: a case study of the Maine laptop initiative," Unpublished Ph.D. Thesis, Nova Southeastern University, Fort Lauderdale, FL, 2006. 
[4] C.-Y. Chang and C. C. Tsai, "The interplay between different forms of CAI and students' preferences of learning environment in the secondary science class," Science Education, vol. 89, no. 5, pp. 707-724, 2005.

[5] C. Mouza, "Learning with laptops: Implementation and outcomes in an urban, underprivileged school," Journal of Research on Technology in Education, vol. 40, no. 4, pp. 447-472, 2008.

[6] M. Dunleavy, S. Dextert, and W. F. Heinecke, "What added value does a 1:1 student to laptop ratio bring to technology-supported teaching and learning?" Journal of Computer Assisted Learning, vol. 23, pp 440-452, 2007.

[7] T. B. Amankwatia, "Teaching with technology for $21^{\text {st }}$-century learning: A multiple case study of a school district's high school laptop initiative," Unpublished Ph.D. Thesis, Lehigh University, Bethlehem, PA, 2008.

[8] A. Jaillet, "What is happening with portable computers in schools?" Journal of Science Education and Technology, vol. 13, no. 1, pp. 115-128, 2004.

[9] H. J. Becker, "How exemplary computer-using teachers differ from other teachers: Implications for realizing the potential of computers in the schools," Journal of Research on Computing in Education, vol. 26, no. 3, pp. 291-321, 1994.

[10] E. A. Davis, D. Petish, and J. Smithey, "Challenges new science teachers face," Review of Educational Research, vol. 76, no. 4, pp. 607-651, 2006.

[11] G. M. Simmie, "Teacher design teams (TSTs) - building capacity for innovation, learning and curriculum implementation in the continuing professional development of in-career teachers," Irish Educational Studies, vol. 26, no. 2, pp. 63-176, 2007.

[12] C. S. Feldman, "Believe it or not: A case study of the role beliefs play in three middle school teachers' use of computers in teaching science," Unpublished Ph.D. Thesis, University of California, Davis, CA, 2004.

[13] T. E. Higgins and M. W. Spitunik, "Supporting teachers' use of technology in science instruction through professional development: A literature review," Journal of Science Education and Technology, vol. 17, pp. 511-521, 2008.

[14] R. K. Yin, Case Study Research: Design and Methods, Thousand Oaks, CA: Sage Publications, 1995

[15] R. Stake, The Art of Case Study Research, Thousand Oaks, CA: Sage Publications, 1995.

[16] M. D. Gall, W. R. Borg, and J. P. Gall, Educational Research: An Introduction, 6th ed., White Plains, NY: Longman, 1996.

[17] C. Marshall and G. B. Rossman, Designing Qualitative Research, Thousand Oaks: Sage Publications, 2006

[18] J. W. Cresswell, Qualitative Inquiry and Research Design: Choosing among Five Traditions, Thousand Oaks, CA: Sage Publications, 1998.

[19] S. B. Merriam, Case Study Research in Education: A Qualitative Approach, San Francisco, CA: Jossey-Bass Publishers, 1988.
[20] I. E. Seidman, Interviewing as Qualitative Research: A Guide for Researchers in Education and the Social Sciences, New York, NY: Teachers College Press, 2006.

[21] O'Leary, The Essential Guide to doing Research, Thousand Oakes, CA: Sage Publications, 2009, pp. 204.

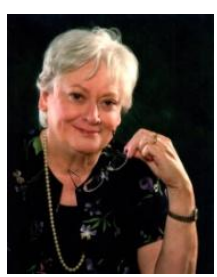

Morag S. Gundy has a B.Sc. from the University of Toronto, and M.Ed., Educational Administration, from the University of Ottawa, and a $\mathrm{Ph}$. D. Education, from the University of Ottawa. Her major field of study is science curriculum, teaching and learning. She is an experienced educator who has worked as a high school teacher, teaching science ( physics, chemistry and biology under the Ontario curriculum, and International Baccalaureate (IB) biology, Higher and Standard levels); IB Coordinator, Vice-Principal, and Head of an IB School in Ontario, Canada.

Dr. Gundy has been active on the Boards of the Canadian Association of Principals, the Conference of Independent Schools (Ontario), the Canadian Association of Independent Schools, International Baccalaureate (North America), and DKG, an International Association of Women Educators, Austin, Texas, USA.

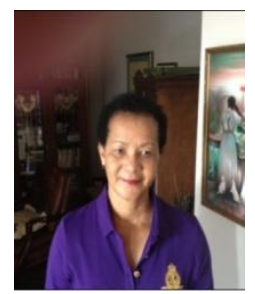

Marie Josée Berger is a professor and she has been the Dean at the Faculty of Education, University of Ottawa. In addition to her expertise in reading, Marie Josée Berger has worked in teaching, learning evaluation, and professional development (specifically for minority communities). She has played a major role in the improving of Ontario's curriculum, both at the elementary and secondary levels. She has not only contributed to linguistic actualization, French-language development, and to the growth of the French programs through the editing of memoirs, but has also been involved in the training of teachers in order to encourage reform.

Her most recent research centers on the portfolio, language skills, as well as on specialized reading intervention from Kindergarten to Grade 8. In cooperation with the Ministry of Education, she has developed a frame of reference for reading that has enabled the training of reading specialists in minority communities and the creation of reading intervention material.

Dr Berger has been the principal investigator for diverse projects for the Ontario Ministry of Education as well as for the Council of Ontario Directors of Education and the Literacy and Numeracy Secretariat, the Ministry of Community and Social Services. Most of the projects are related to curriculum implementation. 